Contributions:

A Study design/planning

B Data collection/entry

C Data analysis/statistics

D Data interpretation

E Preparation of manuscript

F Literature analysis/search

$\mathrm{G}$ Funds collection

\title{
HEARING IMPAIRMENT IN
}

OCULOAURICULOVERTEBRAL DYSPLASIA (GOLDENHAR SYNDROME): LITERATURE REVIEW

\author{
Marek Porowski ${ }^{1 A B E F}$, Henryk Skarżyński ${ }^{1 A E}$, Piotr H. Skarżyński ${ }^{1,2,3 A E}$, \\ Andrzej Pastuszak ${ }^{1 F}$
}

${ }^{1}$ Oto-Rhino-Laryngology Surgery Clinic, World Hearing Centre, Institute of Physiology and Pathology of Hearing, Warsaw/Kajetany, Poland

${ }^{2}$ Heart Failure and Cardiac Rehabilitation, Department of the Medical University of Warsaw, Poland

${ }^{3}$ Institute of Sensory Organs, Warsaw/Kajetany, Poland

Corresponding author: Marek Porowski, M.D., Ph.D., World Hearing Center of the Institute of Physiology and Pathology of Hearing ul. Mokra 17, Kajetany n. Warsaw, 05-830 Nadarzyn, Poland, e-mail: m.porowski@ifps.org.pl

\begin{abstract}
This paper reviews the literature on patients with oculoauriculovertebral dysplasia (OAVD, Goldenhar syndrome) in the context of methods to improve their hearing, an area of interest to otorhinolaryngologists, audiologists, and phoniatrists. The papers reviewed describe individual cases and groups of patients diagnosed with the syndrome. They are of interest due to the range of therapeutic approaches used and the percentage of favourable results. The available literature is sparse, particularly in terms of improving hearing in OAVD. In these patients, degrees of hearing loss or deafness are major problems resulting from complex external, middle, and inner ear defects, which can also lead to speech development disorders. There is therefore a need for a closer look at the syndrome, including how to identify patients, indications for surgical treatment, use of other methods to improve hearing, and methods of rehabilitation.
\end{abstract}

Key words: Goldenhar syndrome $\bullet$ OAVD $\bullet$ therapy $\bullet$ hearing implants

\section{TRASTORNOS DE LA AUDICIÓN EN EL SÍNDROME ÓCULO-AURÍCULO- VERTEBRAL (SÍNDROME DE GOLDENHAR): REVISIÓN DE LA LITERATURA}

\section{Resumen}

El objetivo de este estudio fue revisar la literatura sobre pacientes con en el síndrome óculo-aurículo-vertebral (Síndrome de Goldenhar, $\mathrm{OAVD}$ ) en el contexto de la presencia de trastornos en el área de interés del otolaringólogo, las opciones de tratamiento para estos trastornos y, en particular, la mejora de la audición.

El síndrome de OAVD es un defecto congénito raro que se caracteriza por hipoplasia facial unilateral con defectos oculares y anormalidades esqueléticas. Los rasgos característicos del síndrome fueron descritos por primera vez por Maurice Goldenhar en 1952. El grado de pérdida auditiva puede variar según el tipo de alteración auditiva: de leve a moderado en el caso de una alteración de conducción (en el caso de otitis media crónica con exudado), hasta una pérdida auditiva profunda en el caso de defectos de desarrollo del oído interno con diversas formas de displasia coclear.

Los trabajos que se tuvieron en cuenta se referían tanto a grupos de pacientes como a casos individuales de pacientes con síndrome de Goldenhar. Se consideraron interesantes debido al enfoque terapéutico y al propósito del caso. Al analizar la literatura, se encontró que todavía hay pocas publicaciones que se centran en los problemas auditivos y la mejorar de la audición en el síndrome óculo-aurículo-vertebral. En este grupo de pacientes, el grado de pérdida auditiva es uno de los principales problemas y se debe a la presencia de defectos complejos en el oído externo y medio. A su vez, este problema es la causa de los trastornos del desarrollo del habla.

Por lo tanto, existe la necesidad de un análisis más profundo del problema, incluida la separación de los grupos de pacientes para determinar las indicaciones para el tratamiento quirúrgico, el uso de otros métodos de mejora auditiva y los métodos de rehabilitación.

Palabras clave: síndrome de Goldenhar • OAVD • implante auditivo. 


\title{
НАРУШЕНИЯ СЛУХА ПРИ ПАТОЛОГИИ ГЛАЗА, УХА И ПОЗВОНОЧНИКА (СИНДРОМ ГОЛДЕНХАРА) - ОБЗОР ЛИТЕРАТУРЫ
}

\begin{abstract}
Аннотация
Целью данного исследования является обзор литературы о пациентах с патологией глаза, уха и позвоночника (синдром Голденхара, OAVD) в контексте наличия нарушений, являющихся частью сферы деятельности отоларинголога, вариантов лечения этих нарушений и, в частности, улучшения слуха. Синдром OAVD является редкой врожденной патологией, которая характеризуется односторонней гипоплазией лица с дефектами глаза и скелетными аномалиями. Характерные черты синдромов впервые были описаны Морисом Гольденхаром в 1952 году. Степень нарушения слуха может варьироваться от легкой до умеренной кондуктивной тугоухости в случае хронического среднего отита с экссудатом, до глубокой сенсоневральной тугоухости с дефектами развития внутреннего уха с различными формами кохлеарной дисплазии. Охваченная литература представляла как группы пациентов, так и отдельных пациентов с синдромом Голденхара. Они были признаны интересными из-за представленного терапевтического подхода и цели. При анализе литературы было обнаружено, что все еще существует немного публикаций, посвященных проблемам улучшения слуха при синдроме Голденхара. В этой группе пациентов потеря слуха различной степени является одной из основных проблем, она обусловлена наличием сложных патологий внешнего и среднего уха и является причиной нарушений развития речи. Поэтому существует необходимость более глубокого анализае проблемы, включая разделение групп пациентов для определения показаний к хирургическому лечению, использованию других методов улучшения слуха и методов реабилитации.
\end{abstract}

Ключевые слова: синдром Гольденхара • OAVD • слуховой имплант

\section{ZABURZENIA SŁUCHU W ZESPOLE OCZNO-USZNO-KRĘGOWYM (GOLDENHARA) - PRZEGLĄD PIŚMIENNICTWA}

\begin{abstract}
Streszczenie
Celem niniejszej pracy był przegląd piśmiennictwa dotyczący pacjentów z zespołem oczno - uszno - kręgowym (Goldenhara, OAVD) w kontekście obecności zaburzeń będących w obszarze zainteresowań otolaryngologa, możliwości leczenia tych schorzeń, a w szczególności poprawy słuchu. Zespół OAVD jest rzadka wadą wrodzoną, która charakteryzuje się jednostronnym niedorozwojem twarzy z wadami oczu oraz towarzyszącymi nieprawidłowościami układu kostno - szkieletowego. Charakterystyczne cechy zespołu zostały opisane po raz pierwszy przez Maurice Goldenhar w 1952r. Stopień ubytku słuchu może wahać się od łagodnego i umiarkowanego o typie przewodzeniowym w przypadku przewlekłego zapalenia ucha środkowego $\mathrm{z}$ wysiękiem, do głębokiego niedosłuchu odbiorczego $\mathrm{z}$ wadami rozwojowymi ucha wewnętrznego z różnymi postaciami dysplazji ślimaka. Prace, które wzięto pod uwagę dotyczyły zarówno grup pacjentów jak i pojedynczych przypadków pacjentów z zespołem Goldenhara. Zostały one uznane za interesujące z uwagi na prezentowane podejście lecznicze i cel. Analizując piśmiennictwo stwierdzono, że nadal istnieje niewiele publikacji koncentrujących się na problemach poprawy słuchu w zespole oczno-uszno-kręgowym. W tej grupie pacjentów różnego stopnia niedosłuch jest jednym z większych problemów, wynika z obecności złożonych wad ucha zewnętrznego i środkowego i jest przyczyną zaburzeń rozwoju mowy. Istnieje więc potrzeba głębszej analizy problemu, w tym wyodrębnienia grup pacjentów w celu określenia wskazań do leczenia operacyjnego, zastosowania innych metod poprawy słuchu i sposobów rehabilitacji.
\end{abstract}

Słowa kluczowe: zespół Goldenhara • OAVD • implant słuchowy

\section{Introduction}

Goldenhar syndrome (oculoauriculovertebral dysplasia, OAVD) is a rare congenital malformation clinically manifested by a hemifacial microsomia. Characteristic features of the disease were first described in detail by Maurice Goldenhar in 1952 [1], although it was first mentioned in the second half of the 19th century [2]. In 1969 Gorlin suggested the name "oculoauriculovertebral dysplasia" for the syndrome, since its representative features also include congenital disorders of the spine [3]. The characteristic appearance of patients affected by this disease is due to various degrees of microtia, including anotia, atresia of the external auditory canal, additional outgrowths and preauricular fistulas, micrognathia, and hypoplasia of the jaw and facial muscles. There are at least a few other congenital disorders which also manifest in what is generally described in the Anglo-Saxon literature as "hemifacial microsomia", while the term "Goldenhar syndrome" denotes a special group of these diseases with the distinguishing feature of associated defects of the skeletal system as well as the eye [4-5].

\section{Etiology of the syndrome}

Etiology of the syndrome is not clear and there are many theories trying to explain the developmental disorders of patients affected with the syndrome [6]. Most of the described cases occur sporadically, but families with autosomal dominant and recessive inheritance have also been described $[7,8]$. The influence of environmental factors present at an early stage of fetal development, which cause damage to the cells of the first and second pharyngeal arch, is mainly assumed. These factors include: maternal intake of certain medicines (tamoxifen, thalidomide, cocaine, oral anticoagulants, vitamin A derivatives), alcohol abuse, viral infections, and gestational diabetes mellitus [9-10]. These factors are supposed to cause reduced blood supply or induce local bleeding in the region of the first and second pharyngeal arch, thus causing hypoplasia of tissues originating from these structures $[11,12]$. It is likely that the etiology is complex, and occurrence of the syndrome is affected by both environmental and genetic factors [13]. The incidence of the syndrome varies from 1 in 3,500 to 1 in 5,600 live births, the majority being boys, 
and it generally affects the right side of the head, although about $15 \%$ of cases have developmental disorders on both sides of the face [14].

\section{Structural disorders of the hearing organ}

This literature review includes reports from 36 international publications, accessed from search engines such as PubMed and from hard copies of specialist Polish journals. In all papers diagnosis and treatment of both adults and children was analyzed. The motive for including them all in the materials for this analysis was the widespread presence of damage to the hearing organ. A review of the available literature covering the last 20 years has shown that virtually in all patients with Goldenhar syndrome a group of persistent irregularities can be identified: various degrees of hypoplasia of the pinna (microtia, anotia) co-existing with the stenosis or absence (atresia) of the external auditory canal $[1,3,15,16]$. Other anatomical disorders of the auditory organ described in the literature include preauricular outgrowths, hypoplasia of the tympanic membrane, hypoplasia of the tympanic cavity, hypoplasia and lack of auditory ossicles, improper course of the facial nerve, lack of tensor tympani muscle, lack of chorda tympani, lack of oval and round windows, cochlear hypoplasia, underdevelopment or lack of semicircular canals, enlargement of the vestibular aqueduct, and internal auditory canal defects [17-18].

The broad spectrum of hearing impairments in patients with this syndrome is a result of complex malformations of the external, middle, and in some cases the inner ear, and (as already mentioned) disorders during fetal development of the first and second pharyngeal arch, which results in hypoplasia of structures originating from the arches. The first pharyngeal arch develops, among others, into a malleus, incus, and middle ear, while the second arch develops into the stapes. The labyrinth develops differently, hence defects of the inner ear are less frequently described. The degree of structural disorder differs in each patient: in some the changes are discrete and limited to the external ear, in others they also include the middle and inner ear. As foreshadowed, craniofacial defects most often affect one side only, with bilateral defects being much less frequent [16]. In unilateral cases, the severity of facial hypoplasia is less and the level of hearing loss is asymmetrical.

\section{Hypoacusis in OAVD}

Hypoacusis in patients with Goldenhar syndrome is usually of the conductive type and is associated with developmental disorders of the structures originating from the first and second pharyngeal arch $[19,20]$. Sometimes a sensorineural hearing loss also coexists due to damage to the inner ear, but this type of hypoacusis is less common $[21,21,22]$. The degree of hearing loss can range from mild to moderate disorders of the conductive type (such as with cases of chronic otitis media with effusion) to severe hearing impairment with profound sensorineural hearing loss [23,23]. It is common knowledge that hearing is important for speech development, and in patients with OAV this is one of the leading problems that can significantly affect quality of life. Cohen described hearing loss of various degrees in $92 \%$ of presented patients, which resulted in worse scores in speech perception tests [24]. Skarżyński and associates presented a group of eight patients in which hearing loss was diagnosed in each case, including two with deep bilateral loss [25]. Early recognition of hearing loss, its progression, and early appropriate treatment is therefore key in treating this group of patients.

\section{Treatment of various hearing disorders}

After analyzing the available literature, only a few publications addressed treatment of hearing loss in patients with Goldenhar syndrome $[28,29]$. Most publications adopted a descriptive approach with the presentation of individual cases and audiometric test results, without focusing on treatment. This is probably related to the complexity of these defects in which there are numerous congenital abnormalities whose spectrum differs in each individual patient. Thus, there is no one universal method to improve hearing that can be applied to all affected patients.

The main problem of the vast majority of these patients is a hearing loss associated with atresia of the auditory canal, but since there is still good bone conduction, treatment using bone conduction devices is a natural choice. Bone conduction devices are well known, widely applied, and give very good auditory results, as they usually do in patients with Goldenhar syndrome [26-27]. It should be emphasized, however, that methods involving reconstruction of the external auditory canal are not so effective, and do not improve hearing and speech perception as much as the use of a bone-anchored implant, and usually reconstructions must be combined with the fitting of hearing aids [28].

Hearing losses of the conductive type may also result from malformation of the ossicles. There are only a few reports on effective ossiculoplasty in patients with hypoplasia of the auditory canal, probably a result of the complexity of the defect. Skarżyński and associates described ossiculoplasty performed on three patients [28]. Hearing was improved in two of them, but in the other the degree of middle ear hypoplasia, mainly of the ossicles, prevented it. In one of these cases, hearing improvement was achieved by reconstructing the lost connection between the incus and the deformed stapes. This was done by re-creation of the missing long process of the incus using glass-ionomeric cement to form a stable connection with the stapes. The second case required another type of ossiculoplasty: anterior atticotomy with removal of bone deposits between the malformed ossicles (block of the malleus and incus) and the attic wall. Those deposits completely immobilized the ossicles, causing conductive hearing loss. Most authors, however, focus on classical fitting of hearing aids or the use of bone-anchored implants; these methods are safe and give good results if the inner ear is functioning normally [29-35].

In patients with chronic otitis with effusion, their hypoacusis can be compensated for $[26,28]$. The condition is common in patients with craniofacial malformations of various sorts, but especially with cleft palate. In this group, exploratory tympanotomy is applied to 
remove lesions and ventilation drains are inserted in order to equalize the pressure in the middle ear and preserve hearing as much as possible. In some cases of Goldenhar syndrome, however, an obvious limitation of this method is the critical narrowing or agenesis of the external auditory canal.

As mentioned, sensorineural hearing loss is diagnosed less frequently, and the bilateral deep hearing loss in those patients is unique. The literature on cochlear implantation in such patients is very scarce. To prepare this literature review, a search of the PubMed database with the keywords "cochlear, implant, goldenhar" gave only 5 records, among which only one paper described the use of a brain-stem implant in a child with Goldenhar syndrome. Hitherto only Skarżyński has described the use of cochlear implantation in two patients with OAVD and bilateral deep sensorineural hearing loss [28]. One of them had a structural defect of the inner ear, but in the other the anatomy of the inner ear was normal. Both patients are now permanent users of the implant and have been observed on a long-term basis. Of course, the hearing outcomes obtained after cochlear implantation in deaf patients with structural inner ear defects are typically worse than those with normal anatomy and cochlear damage only at the cellular level, but for these patients cochlear implantation may be the only chance they have to improve or gain hearing [29]. The first cases of using auditory implants in the most severe forms of Goldenhar syndrome, as described by Skarżyński and associates, confirm that even in this complex group of congenital malformations there can be candidates for implantation [28].

\section{Conclusion}

After an analysis of the literature, we find that there are only a few publications dealing with the problem of how to improve hearing in OAVD syndrome. In these patients, a major problem is the variable degrees of hearing loss emanating from complex external and middle ear defects. The usual result is impaired hearing and speech development. There is a need for a deeper analysis of the problem based on the selection of a homogenous group of patients. This would allow detailed recommendations and indications for targeted surgical treatment to be identified, whether it involve use of hearing aids, implants, or tailor-made rehabilitation.

\section{References}

1. Goldenhar M. Associations malformatives de l'oeil et de l'oreille, en particulier le syndrome dermoide epibulbaire-appendices auriculaires-fistula auris congenita et ses relations avec la dysostose mandibulo-faciale. Journal de Genetique Humaine (Geneve), 1952; 1: 243-82.

2. Von Arlt FR. Klinische Darstellung der Krankheiten des Auges zunächst der Binde-, Horn- und Lederhaut dann des Ciliarkörpers. Wilhelm Braumüller, Wien 1881.

3. Gorlin RJ, Jue KL, Jacobsen V, Goldschmidt E. Oculoauriculovertebraldysplasia. J Pediatr, 1963; 63: 991-9.

4. Mansour AM, Wang F, Henkind P, Goldberg R, Shprintzen R. Ocular findings in the facioauriculovertebral sequence (GoldenharGorlin syndrome). Am J Ophthalmol, 1985 Oct 4; 100: 555-9.

5. Anderson PJ, David DJ. Spinal anomalies in Goldenhar syndrome. Cleft Palate Craniofac J, 2005 Sep 5; 42: 477-80.

6. Lam CH. A theory on the embryogenesis of oculo-auriculo-vertebral (Goldenhar) syndrome. J Craniofac Surg, 2000 Nov; 11(6): 547-52.

7. Tasse C, Majewski F, Bohringer S, Fischer S, Ludecke HJ, Gillessen-Kaesbach G, Wieczorek D. A family with autosomal dominant oculo-auriculo-vertebral spectrum. Clin Dysmorphol, 2007 Jan $1 ; 16: 1-7$.

8. Verona LL, Damian NG, Pavarina LP, Ferreira CH, Melo DG. Monozygotic twins discordant for Goldenhar syndrome. J Pediatr (Rio J), 2006 Jan-Feb; 82(1): 75-8.

9. Cullins SL, Pridjian G, Sutherland CM. Goldenhar's syndrome associated with tamoxifen given to the mother during gestation. JAMA, 1994; 271: 1905-6.

10. Lessick M, Vasa J, Israel R. Severe manifestations of oculoauriculovertebral spectrum in a cocaine-exposed infant. J Med Genet, $1991 ; 28: 803-4$.

11. Poswillo D. The pathogenesis of the first and second branchial arch syndrome. Oral Surg Oral Med Oral Pathol, 1973 Mar; 35(3): 302-28.

12. Soltan HC, Holmes LB. Familial occurrence of malformations possibly attributable to vascular abnormalities. J Pediatr, 1986 Jan; 108(1): 112-4.
13. Goret-Nicaise M, Baertz G, Saussoy P, Dhem A. Oculo-auriculo-vertebral spectrum: cranial and vertebral malformations due to focal disturbed chondrogenesis. J Craniofac Genet Dev Biol, 1997 Jan-Mar; 17(1): 35-42.

14. Mellor DH, Richardson JE, Douglas DM. Goldenhar's syndrome. Oculoauriculo-vertebral dysplasia. Arch Dis Child, 1973 Jul; 48(7): 537-41.

15. Muñoz-Pedroza LA, Arenas-Sordo ML. Clinical features of 149 patients with facio-auriculo-vertebral spectrum. Acta Otorrinolaringol Esp, 2013 Sep-Oct; 64(5): 359-62.

16. Pegler JR, Soares DC, Quaio CR, Fernandes N, Oliveira LA, Honjo RS, Bertola DR, Kim CA. Clinical description of 41 Brazilian patients with oculo-auriculo-vertebral dysplasia. Rev Assoc Med Bras, 2016 May-Jun; 62(3): 202-6.

17. Bisdas S, Lenarz M, Lenarz T, Becker H. Inner ear abnormalities in patients with Goldenhar syndrome. Otol Neurotol, 2005 May; 26(3): 398-404

18. Phelps PD, Lloyd GA, Poswillo DE. The ear deformities in craniofacial microsomia and oculo-auriculo-vertebral dysplasia. J Laryngol Otol, 1983 Nov; 97(11): 995-1005.

19. Carvalho GJ, Song CS, Vargervik K, Lalwani AK. Auditory and facial nerve dysfunction in patients with hemifacial microsomia. Arch Otolaryngol Head Neck Surg, 1999 Feb; 125(2): 209-12.

20. Sleifer P, Gorsky NdeS, Goetze TB, Rosa RF, Zen PR. Audiological findings in patients with oculo-auriculo-vertebral spectrum. Int Arch Otorhinolaryngol, 2015 Jan; 19(1): 5-9.

21. Yanagihara N, Yanagihara H, Kabasawa I. Goldenhar's syndrome associated with anomalous internal auditory meatus. J Laryngol Otol, 1979 Dec; 93(12): 1217-22.

22. Scholtz AW, Fish JH, Kammen-Jolly K, Ichiki H, Hussl B, Kreczy A, Schrott-Fischer A. Goldenhar's syndrome: congenital hearing deficit of conductive or sensorineural origin temporal bone histopathologic study. Otol Neurotol, 2001; 22: 501-5.

23. Goetze TB, Sleifer P, Rosa RF, da Silva AP, Graziadio C, Zen PR. Hearing characterization in oculoauriculovertebral spectrum: a prospective study with 10 patients. Am J Med Genet A, 2017 Feb; 173(2): 309-14. 
24. Cohen MS, Samango-Sprouse CA, Stern HJ, Custer DA, Vaught DR, Saal HM, Tifft CJ, Rosenbaum KN. Neurodevelopmental profile of infants and toddlers with oculo-auriculo-vertebral spectrum and the correlation of prognosis with physical findings. Am J Med Genet, 1995 Dec 18; 60(6): 535-40.

25. Skarzyński H, Porowski M, Podskarbi-Fayette R. Treatment of otological features of the oculoauriculovertebral dysplasia (Goldenhar syndrome). Int J Pediatr Otorhinolaryngol, 2009 Jul; 73(7): 915-21.

26. Santarelli G, Redfern RE, Benson AG. Bone-anchored hearing aid implantation in a patient with Goldenhar syndrome. Ear Nose Throat J, 2015 Dec; 94(12): E1-3.
27. Arunachalam PS, Kilby D, Meikle D, Davison T, Johnson IJ. Boneanchored hearing aid quality of life assessed by Glasgow Benefit Inventory. Laryngoscope, 2001 Jul; 111(7): 1260-3.

28. Bouhabel S, Arcand P, Saliba I. Congenital aural atresia: boneanchored hearing aid vs. external auditory canal reconstruction. Int J Pediatr Otorhinolaryngol, 2012 Feb; 76(2): 272-7.

29. Isaiah A, Lee D, Lenes-Voit F, Sweeney M, Kutz W, Isaacson B, Roland P, Lee KH. Clinical outcomes following cochlear implantation in children with inner ear anomalies. Int J Pediatr Otorhinolaryngol, $2017 \mathrm{Feb}$; 93: 1-6. 